\title{
Assessing methods for the density of Ttriatoma dimidiata, the principal vector of Chagas' disease in Guatemala
}

\author{
Carlota Monroy ${ }^{1)}$, Mildred Mejía ${ }^{1)}$, Antonieta Rodas ${ }^{1)}$, \\ Tomoyuki Hashimoto ${ }^{2), 33}$ and Yuichiro TABARU ${ }^{2), 4)}$ \\ "School of Biology, Faculty of Chemistry and Pharmacy University of \\ San Carlos of Guatemala Zone 12, Guatemala City, Guatemala \\ ${ }^{2)}$ Japan International Cooperation Agency-JICA-, 5a Ave. 11-40, Zona 11, Guatemala \\ ${ }^{3)}$ Japan Enviroment Sanitation Center 10-6, Yotsuya-kamicho, Kawasaki, \\ Kanagawa, 210-0828 Japan \\ 4) 100-24, Makinohara 2, Matsudo, Chiba, 270-2267 Japan
}

(Received: 27 April 1998; Accepted: 21 October 1998)

\begin{abstract}
Key words: detecting methods, Triatoma dimidiata, white paper method, excrement, man-hour collection, Guatemala
\end{abstract}

\begin{abstract}
We found a close relation between the number of Triatoma dimidiata collected by the man-hour method and the number of excrement spots of the vector on white paper placed on the wall for a week or more. The sticky trap, hiding box or animal trap was not effective for detecting $T$. dimidiata because of their dull and slow behavior. The flushing-out method is not effective either in estimating the density in the case of $T$. dimidiata, because $T$. dimidiata were not easily flushed-out from their hiding-places by spraying pyrethroid insecticides. We recommend use of the manhour collection or the white paper method for assessing the density of $T$. dimidiata in Guatemala.
\end{abstract}

\section{INTRODUCTION}

To detect the population density of triatomine vectors of Chagas' disease in houses is an important issue for entomological studies and control strategies. The traditional man-hour collection for these vectors of the Chagas' disease is frequently used in research of population density or evaluation of insecticide efficacy in the field. However, this method depends basically on the collector's ability or experience. The principal object of this study was to acquire techniques and methods to detect or collect Triatoma dimidiata in houses and then use them as indicators of insecticide evaluation. Schofield (1978, 1980), Pinchin et al. (1981) and Gürtler et al. $(1993,1995)$ compared detecting techniques for domestic populations of tri- atomines, mainly of $T$. infestans in South America, and Schofield et al. (1987) commented on the advantages and disadvantages of several detection methods. There are a few data in this field on $T$. dimidiata, the principal vector of Chagas' disease in Guatemala. The most widely used way of assessing the domiciliary density of this species is the man-hour collection. Monroy et al. (1995) and Tabaru et al. (1998) reported the results on $T$. dimidiata using man-hour collection. Besides this method, we have tried other methods using sticky papers or animal traps, counting excrement spots on white paper, flushing-out after pyrethroid spraying and markrelease-recapture in Guatemala.

\section{Materials And Methods}

The experiments were performed at the 
Laboratory of Malaria, the Ministry of Public Health and in rural houses at villages of San Juan de Arana, Santa Maria Ixuhatan and Agua Zarca in Department of Santa Rosa, Villa Canales in Department of Guatemala and San Miguel Huite in Department of Zacapa. Triatoma dimidiata and partially Rhodnius prolixus were targetted in these studies.

\section{Traditional man-hour collection}

Experienced technicians collected the bugs inside a house for a certain time period (one person for one hour, two persons for $30 \mathrm{~min}$. or three persons for 20 min.) with a flashlight and a pair of tweezers. The tests were conducted in mud wall houses in four localities. The results of this method were compared with those of other methods.

\section{Counting excrement spots on walls}

A calibrated plastic frame of one square foot was put on the wall where there were spots of triatomine excrement and the number of spots inside the frame including new and old ones was counted. We chose 188 mud wall houses in Santa Maria Ixhuatan. The relation between the number of excrement spots and the number of triatomines collected by the man-hour method was examined.

\section{Adhesive traps in the laboratory and in the field}

Two commercially provided Victor Roach Glue traps were placed at the bottom inside of a small fish tank $(50 \mathrm{~cm} \times$ $35 \mathrm{~cm} \times 40 \mathrm{~cm} \mathrm{~h}$ ) with open or closed covers. This study was carried out in the laboratory under natural temperature. Then we set free 48 bugs in the first and the second instar in the tank. For comparison, we set free the same number of male adults of German cockroach, Blattella germanica, in the same type of tank under the same conditions. Beside the glue trap, two hiding boxes made with corrugated cardboard were placed in the bottom of each tank for their resting places. The accumu- lative numbers adhered on the traps were recorded daily. In the field the same type of trap was put for a week on the wall inside the house where there were many excrement spots. Then we checked the presence of bugs adhered on the traps. We compared the numbers of bugs with those captured by man-hour collection in the same house.

\section{Animal trap collection}

A wooden box $(38 \mathrm{~cm} \times 38 \mathrm{~cm} \times 38 \mathrm{~cm})$ fitted with metal mesh on one side and wood panels on the other three sides, keeping a chicken inside, was set under a bed in a rural mud wall house for a week. Three folded carton shelters $(20 \mathrm{~cm} \times 5$ $\mathrm{cm})$ were set each along the three sides of the box for bug hiding. Each box had passages for triatomines of $30 \mathrm{~cm}$ width and $3 \mathrm{~cm}$ height at each side at the bottom. Food and water for the chicken were prepared every day. One week after, the carton shelters were checked to detect bugs.

\section{White paper method}

We placed a letter-size sheet of white paper $(21 \mathrm{~cm} \times 29 \mathrm{~cm})$ on walls close to beds or chicken nests inside a house for a week; then, we counted the number of excrement spots on the paper. The numbers of spots on the paper were compared with the numbers by the man-hour collection. We tried to use this method for the evaluation of insecticide efficacy before and after the intradomiciliar insecticide treatment.

\section{Flushing-out activity with pyrethroides spraying}

We sprayed $0.075 \%$ water suspension of the commercial formulation of $10 \%$ lambda-cyhalothrine wettable powder at a rate of $50 \mathrm{ml} / \mathrm{m}^{2}$ to mud walls against $T$. dimidiata and to palm-thatched roofs against $R$. prolixus. Ten to 30 minutes after spraying we captured flushed-out bugs and the number was compared with that by the man-hour collection in the same house. 


\section{Mark, release and recapture}

At first we collected the bugs in a house by the man-hour collection; then we marked them with white paint and released them at the entrance of the house. After two weeks, we made another collection in the same way.

\section{Results And Discussion}

The mean number of $T$. dimidiata collected by the traditional man-hour method in the pilot area of Santa Maria Ixuhatan, Department of Santa Rosa was 6.24 in 79 positive houses. We obtained similar numbers of bugs in three other localities: 5.63 in 9 positive houses in San Juan de Arana, 4.72 in 6 positive houses in Agua Zarca, Department of Santa Rosa and 6.90 in 30 positive houses in Villa Canales, Department of Guatemala. The advantage of this method is to be able to obtain live samples. However, it is indispensable for an experinced person to collect bugs. Most of the investigation, surveillance and detecting for triatomines was based on this method (Schofield, 1978, 1980; Pinchin et al., 1981; Gürtler et al., 1993, 1995). This is also appropriate for $T$. dimidiata (Tabaru et al., 1998). Schofield (1978) reported that experienced collectors could collect $23.3 T$. infestans in 15 minutes in one house, whereas inexperienced collectors collected 12.7 in Brasil. This relatively large number of collected $T$. infestans may be due to the difference in population level of the vector.

We compared the numbers of bugs in the same house by the man-hour collec- tion and by counting after demolition (Monroy et al., 1998). The rate of the number by the man-hour collection to the total number counted after the demolition varied from 0.7 to 23.5. The number by the man-hour collection method did not very accurately reflect the total number obtained after demolition of the house.

In the pilot area of Santa Maria Ixhua$\tan$ we counted the number of excrement spots of bugs on walls, using a calibrated plastic frame of one foot square in 170 houses. The mean number of excrement spots was 28 in 74 houses positive for bugs by the man-hour collection, whereas it was only 1.7 in 110 negative houses. A large number of excrement spots on walls suggested the possibility of bug presence in the house. However, we did not use it for evaluation of insecticide efficacy, because the excrement spots were mixed, new and old together.

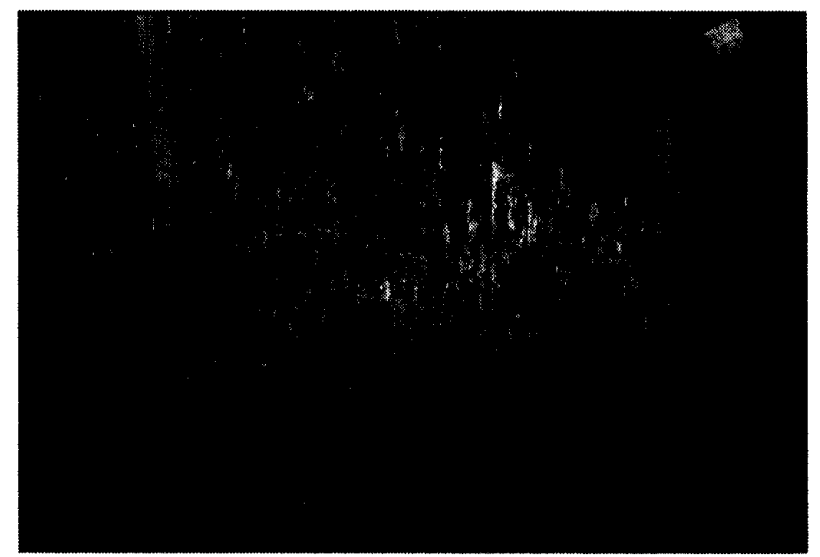

Fig. 1. Bug excrement spots inside a calibrated plastic frame (one foot square) on a wall. The frame was put on the wall where spots were most abundantly found.

Table 1. Results of the traditional man-hour collections for $T$. dimidiata in various locations in Guatemala.

\begin{tabular}{lcccc}
\hline \hline \multicolumn{1}{c}{ Location } & $\begin{array}{c}\text { Number of houses } \\
\text { investigated }\end{array}$ & $\begin{array}{c}\text { Mean number } \\
\text { of bugs }\end{array}$ & $\begin{array}{c}\text { Maximum } \\
\text { number }\end{array}$ & $\begin{array}{c}\text { Minimum } \\
\text { number }\end{array}$ \\
\hline Santa Maria Ixhuatan & 74 & 6.24 & 37 & 1 \\
San Juan de Arana & 9 & 5.63 & 17 & 1 \\
Villa Canales & 30 & 6.90 & 37 & 1 \\
Agua Zarca & 6 & 4.72 & 15 & 1 \\
\hline
\end{tabular}

Houses without bugs were excluded from the data. 
Table 2. Comparison of attractiveness to adhesive traps between $T$. dimidiata and $B$. germanica in laboratory.

\begin{tabular}{ccccc}
\hline \hline Insect & Condition & Day 1 (\%) & Day 2(\%) & Day 3(\%) \\
\hline \multirow{3}{*}{ T. dimidiata } & Cover open & 1 & 1 & 2 \\
& Covered & 1 & 2 & 2 \\
& Total & $2(4.2)$ & $3(6.3)$ & $4(8.3)$ \\
B. germanica & Cover open & 12 & 14 & 17 \\
& Covered & 14 & 19 & 31 \\
& Total & $26(58.3)$ & $33(68.8)$ & $48(100)$ \\
\hline
\end{tabular}

Each 48 number of insects was set free into the same type of fish tank. One trap was without a cover and the other was closed.

Table 3. Comparison of the numbers of $T$. dimidiata by three different methods in 9 rural houses and one chicken house in San Juan de Arana.

\begin{tabular}{cccc}
\hline \hline House no. & $\begin{array}{c}\text { Man-hour } \\
\text { collection }\end{array}$ & $\begin{array}{c}\text { Animal } \\
\text { traps }\end{array}$ & $\begin{array}{c}\text { Shelter } \\
\text { traps }\end{array}$ \\
\hline 1 & 15.0 & 1.0 & 0 \\
2 & 6.7 & 0 & 0 \\
3 & 8.6 & 0 & 0 \\
4 & 10.0 & 0 & 0 \\
5 & 3.3 & 0 & 0 \\
6 & 0.7 & 0 & 0 \\
7 & 4.7 & 0 & 0 \\
8 & 2.7 & 0 & 0 \\
9 & 2.3 & 0 & 0 \\
10 (Chicken house) & 2.3 & 0 & 0 \\
\hline
\end{tabular}

The man-hour collection was triplicated. Traps were set for a week.

A commercially provided Victor Roach Glue trap was evaluated as detecting material for bugs in the laboratory. Table 2 shows the results. All German cockroaches were captured in three days, whereas the number of $T$. dimidiata captured was only $2(4.2 \%)$ in day 1 and 4 $(8.3 \%)$ in day 3 . The bugs seemed to repel the glue traps. In the laboratory, the rest of the bugs hid themselves in the shelter. The glue traps are not effective for bug detection even in the laboratory.

Table 3 shows the results comparing the numbers of bugs obtained by three different methods, in nine rural houses in San Juan de Arana. The mean number collected by the man-hour collection method was 5.63 , whereas only one bug was captured by animal traps in house No. 1 , and no bugs were captured by glue traps at all. These poor results with the latter two passive methods are due to the dull and slow activity of $T$. dimidiata, and they seem to hesitate due to the inexperienced substance. We abandoned the idea of using the glue trap and the animal trap for detecting bugs and evaluating insecticide efficacy in further studies. Schofield et al. (1987) reported the efficacy of the commercialized, artificial refuge box for $T$. infestans with good results even when the bug population was not high. Gürtler et al. (1995) also demonstrated good efficacy with this type of box for the same species in the field.

Schofield (1978), Pinchin et al. (1981), Chuit et al. (1992) and Gürtler et al. (1995) used a sensor box (Biosenor, Biocientifica de Avanzada, Buenos Aires, Argentina) for detecting $T$. infestans in the field. However, Pinchin et al. (1981) and Schofield (1978) emphasized that the sensor box was not suitable for insecticide evaluation, because a long time-period, more than a month, would be required to capture a sufficient number of bugs. Chuit et al. (1992) reported that this sensor box was promising for community-based surveillance in a vector control programme in Argentina, where $T$. infestans was abundant. Gürtler et al. (1995) reported the results using six methods including the sensor box, and he reported that the sensor box was applicable for detecting $T$. infestans. However, T. dimidiata did not 
Table 4. Comparison of changes in the number of bugs man-hour collection and in the number of excrement spots on white paper in the same house, before and after spraying of diazinon wettable powder $\left(600 \mathrm{mg} / \mathrm{m}^{2}\right)$.

\begin{tabular}{|c|c|c|c|c|}
\hline \multirow{2}{*}{ House number } & \multicolumn{2}{|c|}{ Bugs collected by man-hour } & \multicolumn{2}{|c|}{ Excrement spots in white papers } \\
\hline & Before & After 1 month & Before & After 1 month \\
\hline 1 & 5.7 & 0 & 3.5 & 0 \\
\hline 2 & 6.3 & 1 & 2.6 & 0 \\
\hline 3 & 2.0 & 0 & 0.6 & 0.6 \\
\hline 4 & 6.0 & 0 & 0.7 & 0 \\
\hline 5 & 3.0 & 0 & 0.8 & 0 \\
\hline 6 & 4.3 & 0 & 3.2 & 0 \\
\hline 7 & 21.5 & 1 & 6.6 & 0.7 \\
\hline Mean & 6.97 & 0.29 & 2.57 & 0.19 \\
\hline Reduc. \% & & 95.6 & & 93.0 \\
\hline Control & 4.7 & 5 & 6.0 & 5.7 \\
\hline
\end{tabular}

The man-hour collection was done two or three times before insecticide treatment and once after treatment. Five white papers were placed on walls for one week and the number of excrement spots was counted.

Reduction \% was calculated after the adjustment by the numbers of bugs in the control.

enter the carton shelters, which were comparable to the sensor box, placed for a week with the animal trap in the present experient. The behavior seems to be quite different between $T$. dimidiata and $T$. infestans; the former is slower and duller than the latter.

When sheets of white paper are placed on walls for a week, new spots of bug excrement certainly appear on them (Table 4). We used this phenomenon for insecticide evaluation (Tabaru et al., 1998). The number of spots of excrement after insecticide treatment decreased notably, and the change paralleled that by the man-hour collection. The important issue is to select the proper place for the paper, which should be placed where a large number of excrement spots is found.

The disadvantage of this indirect method in the evaluation of insecticides is that twice placement of the paper, before and after treatment, is required and we can not collect live bugs for natural infection studies.

After spraying pyrethroid insecticide some bugs are flushed-out from their resting places. Schofield (1978) suggested that calculating the number of flushed-out bugs should be useful to evaluate insecti- cide efficacy in fields. Table 5 shows the numbers of flushed-out $T$. dimidiata and $R$. prolixus after lambda-cyhalothrine spraying. The number of bugs by the man-hour collection and the number flushed-out in $T$. dimidia were not so different (5.8 vs 7.6 ), wheras in $R$. prolixus they were quite different (6.7 vs 24.7 ).

T. dimidiata seems more difficult to be flushed-out than such other species as $T$. infestans and $R$. prolixus. This method is acceptable not for assessing the density but for detecting the presence of $T$. dimidiata. For evaluating insecticide efficacy it does not seem appropriate because it is necessary to confirm bug density prior to insecticide spraying. In addition, all the bugs and parasites are killed immediately after the treatment of pyrethroid for flushing-out and, accordingly, this method is not acceptable for natural infection studies.

We collected bugs by the man-hour collection, and released them at the entrance of a house after marking them with white paint on the back of the thorax. We tried to recapture them after two weeks in the same house. Table 6 shows the result of this study. Only a small number of the released bugs were recaptured at 2-6 m 
Table 5. Comparison of the numbers of bugs by the man-hour collection and the flushing-out method in $T$. dimidiata and $R$. prolixus.

\begin{tabular}{|c|c|c|c|c|c|}
\hline \multirow{2}{*}{$\begin{array}{l}\text { House } \\
\text { number }\end{array}$} & \multicolumn{2}{|c|}{ T. dimidiata } & \multirow{2}{*}{$\begin{array}{l}\text { House } \\
\text { number }\end{array}$} & \multicolumn{2}{|c|}{ R. prolixus } \\
\hline & $\begin{array}{l}\text { Man-hour } \\
\text { collection }\end{array}$ & Flushed-out & & $\begin{array}{l}\text { Man-hour } \\
\text { collection }\end{array}$ & Flushed-out \\
\hline 1 & 5.5 & 8 & 1 & 13 & 26 \\
\hline 2 & 11.5 & 9 & 2 & 6 & 34 \\
\hline 3 & 3.0 & 9 & 3 & 2 & 7 \\
\hline 4 & 1.0 & 4 & 4 & 8 & 30 \\
\hline \multirow[t]{2}{*}{5} & 8.0 & 8 & 5 & 3 & 7 \\
\hline & & & 6 & 8 & 44 \\
\hline Mean & 5.8 & 7.6 & & 6.7 & 24.7 \\
\hline
\end{tabular}

Test with $T$. dimidiata was done in Agua Zarca, Department of Santa Rosa and with R. prolixus in San Miguel Huite, Department of Chiquimula.

Table 6. Movement of $T$. dimidiata in rural houses using the mark, release and recapture method in Santa Maria Ixhuatan, Department of Santa Rosa.

\begin{tabular}{|c|c|c|c|c|}
\hline $\begin{array}{l}\text { House } \\
\text { number }\end{array}$ & $\begin{array}{l}\text { No. of released bugs } \\
\text { with mark }\end{array}$ & No. of captured bugs & $\begin{array}{l}\text { No. of marked bugs } \\
\text { recaptured }\end{array}$ & $\begin{array}{l}\text { Distance from } \\
\text { released place }(\mathrm{m})\end{array}$ \\
\hline 1 & $7\left(2 \sigma^{7} \sigma^{7}, 2\right.$ 우 우, $\left.3 \mathrm{nf}\right)$ & $4\left(2 \sigma^{\top} \sigma^{\top}, 2 \mathrm{nf}\right)$ & $2\left(1 \sigma^{7}, 1 \mathrm{nf}\right)$ & 2.3 \\
\hline 2 & $4\left(2 \sigma^{\nearrow} \sigma^{\nearrow}, 1\right.$ 우, $\left.1 \mathrm{nf}\right)$ & $2\left(10^{7}, 1\right.$ 우 $)$ & 0 & - \\
\hline 3 & $5(1 \circlearrowleft, 1$ 우, $3 \mathrm{nf})$ & $4\left(2 \sigma^{7} \sigma^{7}, 1\right.$ 우, $\left.1 \mathrm{nf}\right)$ & 0 & - \\
\hline 4 & $3\left(2 \sigma^{\nearrow} \sigma^{\nearrow}, 1\right.$ 우 $)$ & $4\left(1 \sigma^{7}, 2\right.$ 우 우, $\left.1 \mathrm{nf}\right)$ & 1 (1우) & 6.0 \\
\hline 5 & $6\left(2 \sigma^{7} \sigma^{7}, 2\right.$ 우 우, $\left.2 \mathrm{nf}\right)$ & $5\left(2 \sigma^{7} \sigma^{7}, 1\right.$ 우, $\left.2 \mathrm{nf}\right)$ & $1(1 \mathrm{nf})$ & 2.0 \\
\hline 6 & $7\left(1 \sigma^{\nearrow}, 2\right.$ 우 우, $\left.4 \mathrm{nf}\right)$ & 4 (2우 우, $2 \mathrm{nf})$ & 0 & - \\
\hline 7 & $3\left(1 \sigma^{\pi}, 2 \mathrm{nf}\right)$ & $1\left(1 \sigma^{7}\right)$ & 0 & - \\
\hline
\end{tabular}

from the releasing spot. Schofield (1978) reported on the estimation of population density using this method with $T$. infestans in Brazil. But we failed to estimate the density of $T$. dimidiata due to the very small number of bugs recaptured.

\section{ACKNOWLEDGEMENTS}

We thank the technicians of Malaria Division, Mrs. Reginald Pichilla, Heberto Mauricio and Miguel Pérez, for their valued support in the field work. This study was accomplished as a part of The Project of Investigation for the Control of Tropical Diseases, under the Technical Coopertion between Guatemala and Japan, GJET-142.

\section{REFERENCES}

Chuit, R., I. Paulone, C. Wisinivesky-Coli, R. Bo, A. C.
Pérez, S. Sosa-Stani, and E. L. Segura (1992) Result of a first step toward community-based surveillance of transmission of Chagas' disease with appropriate technology in rural areas. Am. J. Trop. Med. Hyg., 46: 444-450.

Gürtler, R. E., R. Chuit, M. C. Cacer and M. B. Castañeda (1995) Detecting domestic vectors of Chagas disease: a comparative trial of six methods in north-west Argenina. Bull. WHO, 73: 487-494.

Gürtler, R. E., J. S. Nicolas, M. C. Cecer, R. Chuit and C. Wisnivesky-Colli (1993) Comparison of two sampling methods for population of Triatoma infestans in north-west Argentina. Med. Vet. Entomol., 7: 238-242.

Monroy, M. C., M. Mejia, A. Rodas, M. Horio, K. Ogata and O. Ochoa (1995) Distribucion intradomiciliar de los vectores de la enfermedad de Chagas comparando los metodos de colecta tradicional y demolicion. Enferm. Trop. Guatemala, Informe Anual, 5: 129-142.

Monroy, C., M. Mejia, A. Rodas, R. Rosales, M. Horio and Y. Tabaru (1998) Comparison of indoor 
searchs with whole house demolition collections of the vectors of Chagas' disease and their indoor distribution. Med. Entomol. Zool., 49: 195-200.

Pinchin, R., D. M. Fanara, C. W. Castleton and A. M. O. Field (1981) Comparison of techniques for detection of domestic infestations with Triatoma infestans in Brazil. Trans. R. Soc. Trop. Med. Hyg., 75: 691-694.

Schofield, C. J. (1978) A comparison of sampling techniques for domestic population of Triatominae. Trans. R. Soc. Trop. Med. Hyg., 72: 449-455.

Schofield, C. J. (1980) Nutritional status of domestic population of Triatoma infestans. Trans. $R$. Soc. Trop. Med. Hyg., 74: 770-778.

Schofield, C. J., D. M. Minter and R. J. Tonn (1987) The Triatominae bugs-biology and control. Vector Control Series, $W H O / V B C / 87: 941$.

Tabaru, Y., C. Monroy, A. Rodas, M. Mejía and R. Rosales (1998) Chemical control of Triatoma dimidiata and Rhodnius prolixus (Reduviidae: Triatominae), the principal vectors of Chagas' Disease in Guatemala. Med. Entomol. Zool., 49: 87-92.

\section{摘要}

家屋内での Triatoma dimidiata の生息密度 推測について

Carlota Monroy ${ }^{11}$, Mildred Mejía ${ }^{11}$, Antonieta Rodas ${ }^{1)}$, Tomoyuki Hashimoto ${ }^{2), 3)}$ and Yuichiro TABARU ${ }^{2), 4)}$

1) School of Biology, Faculty of Chemistry and Pharmacy, University of San Carlos of Guatemala, Zone 12, Guatemala City, Guatemala

2) 国際協力事業団，グアテマラ共和国，熱帯病研究プロ ジェクト 5a Ave. 11-40, Zona 11, Guatemala 3) 日本環境衛生センター

（テ210-0828 川崎市川崎区四谷上町 10-6）

4) テ270-2267 千葉県松戸市牧, 原 2-100-24

サシガメが生息する民家の壁に白紙 $(21 \mathrm{~cm} \times 29 \mathrm{~cm})$ を一定期間設置してその上に新しく付着する䔬の数をサ シガメの生息数の指標及び効果判定の評価にできる事を 明らかにした。 ゴキブリ捕獲用粘着トラップ, シェル ター，動物䀠等を「限定時間採集」と比較したが，何れ 6 T. dimidiata には有効でなかった．また，ピレスロイ ド系殺虫剤散布後の Flush-outする数あ少なかった。こ れは, 本種の行動に起因すると判断した. 